\title{
INNER CITY OR OUTSKIRTS: WHERE ARE RESIDENTS MORE SATISFIED? THE CASE OF JELGAVA
}

\section{lekšpilsēta vai nomales: kur iedzīvotāji ir vairāk apmierināti? Jelgavas piemērs}

\author{
Liga Feldmane \\ University of Latvia, Faculty of Geography and Earth Sciences \\ ljankava@gmail.com
}

\begin{abstract}
Residential satisfaction is an important issue in any urban development policy. In order to ascertain the level of residential satisfaction in Jelgava in 2018 a population survey was conducted, in which 961 residents were questioned. Since the urban environment of Jelgava is not homogeneous, respondents were grouped according to the place of residence in two parts of the city - the inner city and the outer city. The results revealed that the overall satisfaction with life in Jelgava is relatively high, but this indicator is not influenced by the respondent's place of residence in the urban area. There were no statistically significant differences between respondent satisfaction in the inner city and/or the outskirts with life in general, household financial situation, educational facilities, air quality, noise level, cleanliness and/or job opportunities. By contrast the location of residence in one or another urban zone affects satisfaction with public transport, health-care services, sports facilities, cultural facilities, the state of the streets and buildings, public places, green areas and the availability of retail shops - respondents living in the inner city are more satisfied with all of these factors compared with those living on the city outskirts.
\end{abstract}

Keywords: residential satisfaction, urban zones, second-tier city, Jelgava

\section{Introduction}

The number of satisfaction studies in different fields of science since the middle of the 20th century has grown rapidly, as identifying the level of satisfaction can help to improve services, products and policies. The expressed interest of geographers in satisfaction research is related to spatial expressions of satisfaction and thus residential satisfaction is most often studied. It is a complex concept influenced by various environmental and socio-demographic variables ( $\mathrm{Lu}$ 1999). According to Amerigo and Aragones (1997) residential satisfaction is defined as the positive emotional state an individual feels towards his or her living environment and which will influence his or her behaviour to maintain or increase the link with that environment. It is often associated with the migration intentions of residents (Frijters et al. 2011) and especially within neighbourhoods in the same city (Nowok et al. 2018). Previous research has proved the relationship: the less satisfied a person is with residence, the greater is his desire to move (Fang 2006; Nowok et al. 2018).

Residential satisfaction may be studied from different viewpoints and factors that influence it, and one of these is the spatial factor. Previous studies have revealed that place of residence in the urban morphological structure affects residential satisfaction (Dekker et al. 2011). There are studies which reveal that suburbanites tend to be more satisfied than centrality residents (Speare 1974), residents of semi-central areas are more satisfied than others (Gentile 2015; Kovacs and Douglas 2004). At the same time there are research studies that did not find an impact as a result of location. For example, 
Gentile (2005) points out that residential satisfaction varies more significantly according to housing types rather than according to a neighbourhood's distance from the city center.

Residential satisfaction in the context of Central-Eastern Europe has been studied in the Czech Republic (Temelova et al. 2012; Hanák et al. 2015; Špačková et al. 2016); Estonia (Kährik et al. 2011); Poland (Gorczyca and Grabinski 2017). In the academic field residential satisfaction in Latvia has been little studied. Parsova and Sidelska (2017) have studied household opinion regarding their accommodations and criteria that influence this in the cities and rural areas of Latvia. Krūmiņš, Bērziņš and Sechi (2018) have investigated how both mobility and static factors affect the assessment of young individuals with regard to the question of residential satisfaction in Rīga. Overall residential satisfaction has also been studied in Jelgava (Feldmane 2018), but residential satisfaction in the different urban zones within medium sized cities of Latvia has not yet been researched. As a consequence of this situation the research question for this study is to investigate how location of residence in the inner city or outskirts affects residential satisfaction in the case of Jelgava.

\section{Data and Methods}

In 2018 a survey of the residents of Jelgava (hereinafter - The Survey) was carried out in order to ascertain the level of satisfaction with the place of residence, and 961 persons in total were interviewed. Respondents were asked to assess their satisfaction with life in Jelgava and the factors affecting this according to the Likert 5point scale, where "1" is "very dissatisfied" and "5" - "very satisfied". The factors affecting residential satisfaction in Jelgava were as follows: overall life satisfaction, satisfaction with the household financial situation, public transport, health-care services, sports facilities, cultural facilities, the state of the streets and buildings, public spaces, green spaces, availability of retail shops, educational facilities, the quality of the air, noise levels, cleanliness, safety and job opportunities.

Within the framework of the study, the city of Jelgava was divided into two urban areas - the inner city and the outer city (Figure 1). The inner city is located in the central part of the city, it is historically the oldest part of Jelgava, dominated by apartment complexes built during the years of Soviet socialism. The inner city is also an area where business and trading activities dominate. By contrast, the outer city is the territory outside the city center. It is not homogeneous, and it contains both housing estates built during the Soviet socialist era, as well as private houses. The growth of private houses built in recent years is vividly evident in this urban zone. 


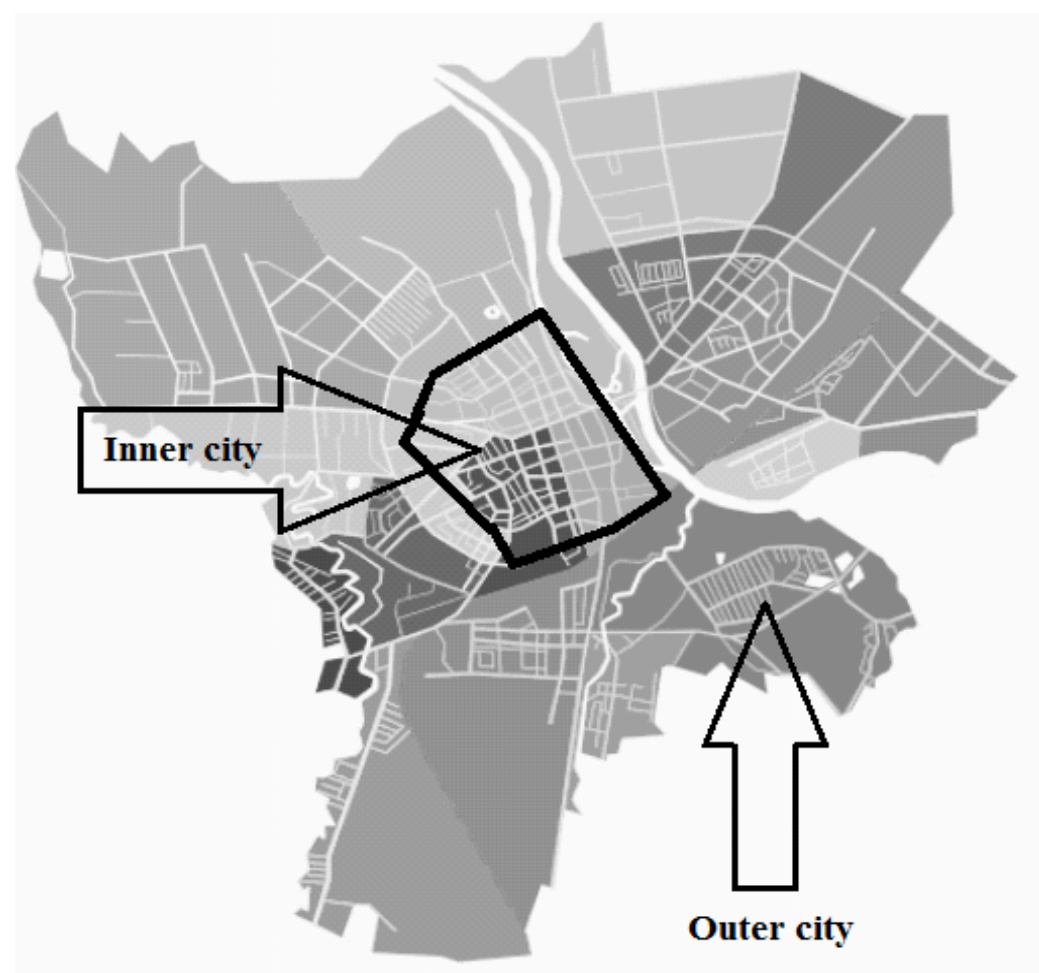

Figure 1. Urban zones of Jelgava (author's figure based on Neighborhoods of Jelgava data)

Data arrays were grouped according to divided urban zones in order to assess whether there were differences in residential satisfaction between the two zones and data descriptives are depicted in Table 1.

Table 1. Descriptive statistics

\begin{tabular}{|c|c|c|c|c|}
\hline & & \multirow[b]{2}{*}{$\mathbf{N}$} & \multicolumn{2}{|c|}{ Urban zone } \\
\hline & & & Inner city & Outer city \\
\hline Total & & 961 & $100 \%$ & $100 \%$ \\
\hline Gender & male & 337 & $37.6 \%$ & $33.0 \%$ \\
\hline & female & 624 & $62.4 \%$ & $67.0 \%$ \\
\hline Age & $18-25$ & 303 & $36.5 \%$ & $27.6 \%$ \\
\hline & $25-35$ & 249 & $25.6 \%$ & $26.1 \%$ \\
\hline & $35-45$ & 137 & $12.7 \%$ & $15.5 \%$ \\
\hline & $45-65$ & 172 & $16.5 \%$ & $19.0 \%$ \\
\hline & 66 and more & 100 & $8.7 \%$ & $11.8 \%$ \\
\hline Nationality & latvian & 791 & $84.9 \%$ & $80.2 \%$ \\
\hline & other & 170 & $15.1 \%$ & $19.8 \%$ \\
\hline Marital status & lives alone & 401 & $46.8 \%$ & $37.7 \%$ \\
\hline & $\begin{array}{l}\text { married or cohabiting } \\
\text { couple }\end{array}$ & 560 & $53.2 \%$ & $62.3 \%$ \\
\hline Type of housing & $\begin{array}{l}\text { flat in an apartment } \\
\text { house }\end{array}$ & 577 & $67.1 \%$ & $54.5 \%$ \\
\hline
\end{tabular}




\begin{tabular}{|l|l|c|c|c|}
\hline \multirow{2}{*}{} & \multicolumn{2}{c|}{} & \multicolumn{2}{c|}{ Urban zone } \\
\cline { 3 - 5 } & & $\mathbf{N}$ & Inner city & Outer city \\
\cline { 2 - 5 } & private house & 231 & $14.4 \%$ & $31.7 \%$ \\
\cline { 2 - 5 } & dormitory & 153 & $18.6 \%$ & $13.8 \%$ \\
\hline \multirow{3}{*}{$\begin{array}{l}\text { Period of house } \\
\text { construction }\end{array}$} & before 1946 & 43 & $5.2 \%$ & $3.9 \%$ \\
\cline { 2 - 5 } & $1946-1991$ & 753 & $84.9 \%$ & $73.1 \%$ \\
\cline { 2 - 5 } & $1991-2001$ & 84 & $5.9 \%$ & $11.0 \%$ \\
\cline { 2 - 5 } & after 2001 & 81 & $4.0 \%$ & $11.9 \%$ \\
\hline
\end{tabular}

Since results of the Kolmogorov - Smirnov test for normality data were found to be inconsistent with the normal distribution, a non-parametric data processing method - the Mann Whitney test - was used in the data analysis process to better determine whether there were statistically significant differences in residential respondent satisfaction between the now clearly defined urban zones of Jelgava.

\section{Results}

Overall satisfaction with life in Jelgava has been assessed as rather high in that $80.2 \%$ of all respondents answered that they are somewhat satisfied or very satisfied with it. Although respondents from the inner city have indicated that they are slightly more satisfied with life in the city as $82.5 \%$ of respondents from inner city and $78.4 \%$ from outskirts are satisfied (Figure 2), we must observe, though, that comparing these results with the Mann Whitney test, no statistical significance is observed. This means that in this particular case study, location of residence does not influence overall satisfaction with city.

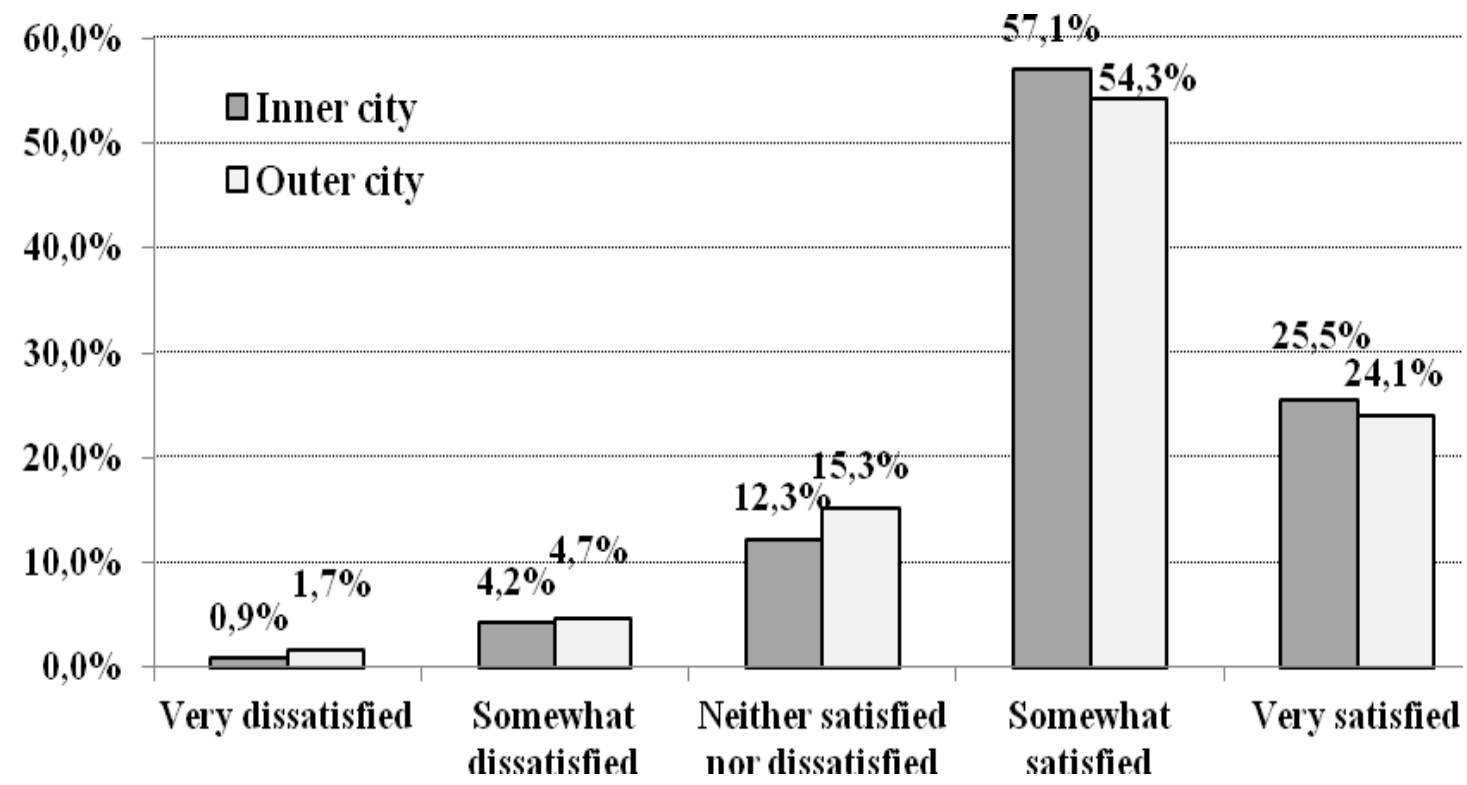

Figure 2. Satisfaction with life in Jelgava in different urban zones, \% (author's figure)

The Survey respondents were also asked to evaluate their satisfaction level with life in general, taking into account their household financial situation and various other factors that could influence residential satisfaction. Overall, the residents of Jelgava 
are the most satisfied with their green spaces, educational facilities, the availability of retail shops, cleanliness and access to cultural facilities, while satisfaction is lowest with public transport, lack of job opportunities, the state of streets and the building and health care services. Statistical differences between satisfaction of these factors in the two urban zones were tested (Table 2) and no differences were observed between respondent satisfaction with life in general, in financial situation, with educational facilities, the quality of the air, the noise level, cleanliness and job opportunities. By contrast, urban zone respondents expressed satisfaction with such factors as public transport, health-care services, sports facilities, access to cultural facilities, the state of the streets and buildings, public spaces, green spaces and availability of retail shops.

Table 2. Comparing the differences between urban zone involvement regarding residential satisfaction with the Mann-Whitney test

\begin{tabular}{|c|c|c|c|}
\hline $\begin{array}{c}\text { Grouping } \\
\text { variable }\end{array}$ & Factor & $\mathbf{Z}$ & p-value \\
\hline \multirow[t]{17}{*}{ Urban zones } & Satisfaction with life in Jelgava & -1.27 & 0.204 \\
\hline & Satisfaction with life in overall & -1.519 & 0.129 \\
\hline & Satisfaction with financial situation & -0.681 & 0.496 \\
\hline & Public transport & -2.964 & 0.003 \\
\hline & Health care services & -2.391 & 0.017 \\
\hline & Sports facilities & -2.409 & 0.016 \\
\hline & Cultural facilities & -4.264 & 0.000 \\
\hline & The state of the streets and buildings & -3.628 & 0.000 \\
\hline & Public spaces & -2.27 & 0.023 \\
\hline & Green spaces & -2.716 & 0.007 \\
\hline & Availability of retail shops & -3.601 & 0.000 \\
\hline & Educational facilities & -0.189 & 0.85 \\
\hline & The quality of the air & -0.687 & 0.492 \\
\hline & The noise level & -0.61 & 0.542 \\
\hline & Cleanliness & -1.614 & 0.106 \\
\hline & Safety & -2.939 & 0.003 \\
\hline & Job opportunities & -0.498 & 0.619 \\
\hline
\end{tabular}

To determine in which urban area residents are more satisfied with the abovementioned factors, the mean levels of satisfaction for each aspect in both urban areas were compared. Despite the fact that the respondent group from the inner city is mostly younger than those from the outer city and respondent housing in the city center is dominated by flats in apartment buildings built in the Soviet era of socialism - factors, which could be related with lower residential satisfaction - nevertheless, as it is illustrated in Table 3, the satisfaction level of all statistically different factors is higher in the inner city. Those who live in the city center most likely do not use public 
transport or use it rarely because everything is within walking distances. Therefore, respondents from the inner city more often have answered that they are neither satisfied nor dissatisfied $(44.3 \%)$ and $23.3 \%$ were dissatisfied with public transport in Jelgava, while $35.5 \%$ of respondents living on the outskirts were dissatisfied. Naturally, residents of the inner city were also more satisfied with health-care services, cultural facilities, public spaces and the availability of retail shops as the inner city is the area where the main commercial, cultural and medical institutions are concentrated. On the other hand, as it might be expected, residents from the outskirts must be more satisfied with the green spaces and the state of the streets and buildings as the outskirts are associated with more green areas because of forests at the edge of the city and newer housing stock. Nevertheless, the results of the Survey illustrate an opposite situation as the satisfaction level with green spaces and the state of the streets and buildings is lower than in the city center. The main reason for these results may be explained by the fact that the inner city of Jelgava has become more attractive in recent years; there are many parks and squares while the outer city has experienced fewer changes. While the streets of the inner city have been repaired, there are many smaller streets and roads around the city center that are still in poor condition and without asphalt pavement.

Table 3. Comparing the means between urban zone involvement regarding residential satisfaction

\begin{tabular}{|l|c|c|c|c|c|c|}
\hline \multicolumn{1}{|c|}{ Factor } & \multirow{2}{*}{ Min } & \multirow{2}{*}{ Max } & \multicolumn{2}{c|}{ Inner city } & \multicolumn{2}{c|}{ Outer city } \\
\cline { 4 - 7 } & & & $\mathbf{N}$ & Mean & N & Mean \\
\hline $\begin{array}{l}\text { Satisfaction with life in } \\
\text { Jelgava }\end{array}$ & 1 & 5 & 424 & 4.02 & 536 & 3.94 \\
\hline $\begin{array}{l}\text { Satisfaction with life in } \\
\text { overall }\end{array}$ & 1 & 5 & 425 & 4.02 & 536 & 3.99 \\
\hline $\begin{array}{l}\text { Satisfaction with } \\
\text { financial situation }\end{array}$ & 1 & 5 & 422 & 3.58 & 535 & 3.50 \\
\hline Public transport & 1 & 5 & 421 & 3.11 & 534 & 2.89 \\
\hline Health care services & 1 & 5 & 423 & 3.34 & 533 & 3.18 \\
\hline Sports facilities & 1 & 5 & 421 & 3.84 & 533 & 3.73 \\
\hline Cultural facilities & 1 & 5 & 425 & 3.95 & 535 & 3.76 \\
\hline $\begin{array}{l}\text { The state of the streets } \\
\text { and buildings }\end{array}$ & 1 & 5 & 425 & 3.35 & 536 & 3.11 \\
\hline Public spaces & 1 & 5 & 424 & 3.77 & 536 & 3.65 \\
\hline Green spaces & 1 & 5 & 425 & 4.06 & 535 & 3.94 \\
\hline $\begin{array}{l}\text { Availability of retail } \\
\text { shops }\end{array}$ & 1 & 5 & 424 & 4.03 & 536 & 3.81 \\
\hline Educational facilities & 1 & 5 & 423 & 3.98 & 536 & 4.01 \\
\hline The quality of the air & 1 & 424 & 3.69 & 536 & 3.66 \\
\hline The noise level & 1 & 423 & 3.50 & 536 & 3.46 \\
\hline
\end{tabular}




\begin{tabular}{|l|c|c|c|c|c|c|}
\hline \multirow{2}{*}{ Factor } & \multirow{2}{*}{ Min } & \multirow{2}{*}{ Max } & \multicolumn{2}{c|}{ Inner city } & \multicolumn{2}{c|}{ Outer city } \\
\cline { 4 - 7 } & & & N & Mean & N & Mean \\
\hline Cleanliness & 1 & 5 & 425 & 3.94 & 535 & 3.83 \\
\hline Safety & 1 & 5 & 425 & 3.80 & 536 & 3.64 \\
\hline Job opportunities & 1 & 5 & 425 & 3.03 & 535 & 3.01 \\
\hline
\end{tabular}

\section{Conclusion}

Residential satisfaction is a complex concept that includes individual satisfaction with their living environment and its perception as an important condition for the further development of the urban environment. Although the results of this study reveal that an overall satisfaction with life in Jelgava does not depend on the urban area in which the resident lives, the satisfaction level is tied to several factors that influence overall residential satisfaction in the city and varies between the inner city and the outskirts of Jelgava. Satisfaction with such factors as public transport, health-care services, sports facilities, access to cultural facilities, the state of the streets and buildings, public spaces, green spaces and the availability of retail shops is significantly higher in the inner city, as the main commercial, cultural and administrative activities are located in the city center. At the same time, satisfaction level with life in general, the financial situation, educational facilities, the quality of the air, the noise levels, cleanliness and job opportunities is almost the same in the inner city as it is in the outskirts. The results confirm that distance to the city center is an important issue also in medium-sized cities and that the outer city is an area where public services and infrastructure should not be neglected among the further improvements and developments to provide equal living conditions for all residents.

\section{Acknowledgement}

This study was supported by National Research Program Project N.VPP-IZM2018/1-0015.

\section{Kopsavilkums}

Dzīves vietas novērtējums ir pozitīvs emocionāls stāvoklis, ko indivīds izjūt pret savu dzīvesvietu un kas notur vai palielina saikni ar šo dzīvesvietu (Amerigo and Aragones 1997). Savukārt ir būtiski noskaidrot š̄ novērtējuma līmeni un ņemt vērā ikvienu vietu turpmākās attīstības plānošanā. Lai noskaidrotu dz̄ivesvietas novērtējuma līmeni, 2018. gadā Jelgavā tika īstenota iedzīvotāju aptauja, kurā kopumā tika aptaujāts 961 pilsētas iedzīvotājs. Tā kā Jelgavas urbānā vide nav viendabīga, dzīvesvietas atrašanās dažādās pilsētas urbānajās zonās var atšķirīgi ietekmēt dzīvesvietas novērtējumu, tādēl respondenti pētījuma gaitā tika sagrupēti pēc dzīvesvietas divās pilsētas daḷās - iekšpilsētā un ārpilsētā. Rezultāti parādīja, ka kopējais dz̄ivesvietas novērtējums Jelgavā ir visai augsts, jo 80,2\% no respondentiem kopumā ir apmierināti ar dz̄ivi Jelgavā, turklāt šo rādītāju neietekmē respondenta dzīvesvieta pilsētas urbānajā telpā. Statistiski būtiskas atšķirības starp iekšpilsētas un ārpilsētas respondentu atbildēm netika konstatētas apmierinātībā ar dzīvi kopumā, mājsaimniecības finansiālo situāciju, izglīî̄bas iestādēm, gaisa kvalitāti, trokšņu līmeni, sakoptību un darba iespējām. Tajā pašā laikā dzīvesvietas atrašanās vienā vai otrā urbānajā zonā ietekmē apmierinātību ar sabiedrisko transportu, veselības aprūpes pakalpojumiem, sporta un kultūras objektiem, ielu un ēku stāvokli, publiskajām vietām, zaļajām zonām, kā arī mazumtirdzniecības veikalu pieejamību, turklāt tika konstatēts, ka respondenti, kas 
dzīvo iekšpilsētā, visus šos faktorus vērtē augstāk nekā iedzīvotāji, kuru dzīves vieta atrodas ārpus pilsētas centra.

\section{References}

Amerigo, M. and Aragones, J. (1997). A theoretical and methodological approach to the study of residential satisfaction. Journal of Environmental Psychology, 17. 47-57.

Dekker, K., de Vos, S., Musterd, S. and van Kempen, R. (2011). Residential satisfaction in housing estates in European cities: A multi-level research approach, Housing Studies, 26 (4), 479-499.

Feldmane, L. (2018). Life quality assessment in the city of Jelgava. Proceedings of Conference Economic Science for Rural Development: Integrated and Sustainable Regional Development, Marketing and Sustainable Consumption, 48, 85-92.

Gentile, M. (2005). Urban residential preferences and satisfaction in the former Soviet Union: Results from a survey in Ust'-Kamenogorsk, Kazakhstan. Urban Geography, 26 (4), 296-327.

Gentile, M. (2015). The "Soviet" factor: exploring perceived housing inequalities in a midsized city in the Donbas, Ukraine. Urban Geography, 36 (5), 696-720.

Gorczyca, K. and Grabinski, T. (2017). Ageing in place: residential satisfaction in Polish housing-estate communities. Ageing \& Society, 38 (12), 1-25.

Kährik, A., Leetmaa, K. and Tammaru, T. (2011). Residential decision-making and satisfaction among new suburbanites in the Tallinn urban region, Estonia. Cities, 29 (1), 49-58.

Kovacs, Z. and Douglas, M. (2004). Hungary: From socialist ideology to market reality. In: Turkington, R., van Kempen, R. and Wassenber, F. (eds.) Highrise Housing in Europe: Current Trends and Future Prospects. Housing and Urban Policy Studies. Delft: University Press, 231-248.

Krūmiņš, J., Sechi, G. and Bērziņš, M. (2018). Residential satisfaction and mobility behaviour among the young: insights from the post-Soviet city of Riga. BELGEO Thematic Issue: Mobility and the international migration of young people: new models, new behaviours: https://journals.openedition.org/belgeo/28347

Neighborhoods of Jelgava (Jelgavas apkaimes). (2019). http://jelgavas-ielas.lv/apkaimes/ (01.02.2019).

Špačková P., Dvořáková N. and Tobrmanová, M. (2016). Residential satisfaction and intention to move: the case of Prague's new suburbanites', Geografiska Annaler: Series B, Human Geography, 98 (4), 331-348.

Speare, A. (1974). Residential satisfaction as an intervening Variable in residential mobility. Demography, 11 (2), 173-188.

Parsova V. and Sidelska A. (2017). Sustainability of dwellings in the context of their residents' opinion. Proceedings of Conference "Engineering for Rural Development", 994-999.

Fang, Y. (2006). Residential satisfaction, moving intention and moving behaviours: a study of re-developed neighbourhoods in inner-city Beijing. Housing Studies, 21 (5), 671-694.

Nowok, B., Findlay, A. and McCollum, D. (2018). Linking residential relocation desires and behaviour with life domain satisfaction. Urban Studies, 55 (4), 870-890.

Frijters, P., Johnston, D.W. and Shields, M.A. (2011). Life satisfaction dynamics with quarterly life event data. Scandinavian Journal of Economics, 113 (1), 190-211.

Temelova J. and Dvorakova N. (2012). Residential satisfaction of elderly in the city center: The case of revitalizing neighbourhoods in Prague. Cities, 29 (5), 310-317. 